\title{
ORGANIC CARBON CYCLE IN THE ULLEUNG BASIN SEDIMENT, EAST/JAPAN SEA
}

\author{
LEE, T. ${ }^{1}-$ JUNG, S. K. ${ }^{2}-$ KIM, K. H. ${ }^{3}-$ LEE, S. H. ${ }^{4}-$ SON, Y. B. ${ }^{1 *}$ \\ ${ }^{1}$ Jeju Environmental Research Center, Korea Institute of Ocean Science \& Technology \\ Iljudong-ro 2670, Gujwa, Jeju 63349, Republic of Korea \\ (e-mail: thlee@kiost.ac.kr; phone: +82-64-798-6072; fax: +82-64-798-6085) \\ ${ }^{2}$ Marine Security and Safety Research Center, Korea Institute of Ocean Science \& Technology \\ 49111 Busan, Republic of Korea \\ ${ }^{3}$ Deep-sea Mineral Resource Research Center, Korea Institute of Ocean Science \& Technology \\ 49111 Busan, Republic of Korea \\ ${ }^{4}$ Department of Oceanography, Pusan National University, 46241 Busan, Republic of Korea \\ ${ }^{*}$ Corresponding author \\ e-mail: sonyb@kiost.ac.kr; phone:+82-64-798-6071; fax:+82-64-798-6085
}

(Received $30^{\text {th }}$ Apr 2019; accepted $4^{\text {th }}$ Jul 2019)

\begin{abstract}
Organic carbon (OC) fluxes in the Ulleung Basin (UB) sediments, East/Japan Sea (E/JS) were investigated through geochemical analyses and sediment chamber experiment. The UB sediment has high organic carbon contents of over $2 \%$ and the mean $\mathrm{C} / \mathrm{N}$ molar ratio is 7.09 , therefore suggesting that the organic matter deposited in the UB is predominantly of marine origin. Apparent sedimentation rates (ASR) calculated from excess ${ }^{210} \mathrm{~Pb}$ activity distribution, ranged between $0.036-0.047 \mathrm{~cm} \mathrm{year}^{-1}$. The mass accumulation rates (MAR) calculated from porosity, grain density (GD) and ASR, ranged between 131-184 $\mathrm{g} \mathrm{m}^{-2}$ year $^{-1}$. Input fluxes of OC (IF) and burial fluxes of OC (BF) varied between 7.89-11.08 and 2.02-3.10 gC men mear $^{-1}$, respectively. Regenerated fluxes of OC (RF) estimated with oxygen consumption rate, varied between 6.22-6.59 $\mathrm{gC} \mathrm{m}^{-2}$ year $^{-1}$. However, the RF calculated by subtracting $\mathrm{BF}$ from IF, varied between 5.87-7.98 $\mathrm{gC} \mathrm{m}^{-2}$ year $^{-1}$. The proportions of the IF, $\mathrm{RF}$, and $\mathrm{BF}$ to the primary production $\left(177.1 \mathrm{gC} \mathrm{m}^{-2}\right.$ year $\left.^{-1}\right)$ in the UB were about $5.4 \%, 3.9 \%$, and $1.5 \%$, respectively. These proportions were over 5 times higher than the average of world open ocean. Based on these results, the UB appears to play an important role in the deposition and removal of organic carbon in the E/JS.
\end{abstract}

Keywords: particulate organic carbon (POC), input flux of organic carbon (IF), regenerated flux of organic carbon $(R F)$, burial flux of organic carbon $(B F)$, Ulleung Basin $(U B)$

\section{Introduction}

The amount of organic matter in marine sediments reflect the supply and preservation of organic materials from marine and terrestrial sources (Tissot et al., 1980; Summerhayes, 1981). The export and preservation of organic matter from the surface waters, where they are produced, down to the basin floor determines the role of basins as a potential carbon sink. The export fluxes of particulate organic carbon (POC) play an important role in the transfer of carbon between the atmosphere and the ocean (Savoye et al., 2006; Waples et al., 2006). In the open ocean, the main source of particles is biological production. Organic particles are produced from carbon fixation through photosynthesis and uptake of nutrients. Most of the POC is recycled in the surface water by decomposition into dissolved organic carbon and remineralization into inorganic carbon. Only a small fraction of POC is exported from the euphotic layer and subsequently either recycled in the deep waters or reaching the sediments. The POC 
export out of the surface layer is the most important process for the transport of atmospheric $\mathrm{CO}_{2}$ to the deep ocean (Trull et al., 2011).

Export of organic material from the euphotic zones into deeper oceanic zones occurs in different ways. Particulate materials as biogenic materials, detrital materials and fecal pellets are transported by gravitational settling and lateral transport. Whereas the dissolved organic matter export largely depends on the extent of downward diffusion and mixing. Generally, most of this particle flux is affected by early diagenesis during settling: concentration decreases significantly with increasing water depth preferentially due to biogenically mediated organic matter degradation and dissolution processes (Suess, 1980). So, only a small fraction, which is not reintroduced back into the oceanic water column and the euphotic zone, reaches marine sediments.

Marine sediments acting as important sinks for organic matter are known from, for example, upwelling areas, shelf mud depocentres and marginal sea basins (Leipe et al., 2011). Organic carbon (OC) in marine sediments represents a major component of the global carbon cycle (Seiter et al., 2004). OC cycles in deep basin sediments are of interest for assessment of the long-term removal of $\mathrm{CO}_{2}$ from surface waters and the regeneration of nutrients from the sediments (Eimeis et al., 2000). A key step in this cycle is represented by the reminelalization of organic matter at the sediment-water interface, via a number of oxidative processes.

The E/JS is a semi-enclosed marginal sea between continental Asia and the Japanese archipelago, connected to open ocean through straits 12-140 m in depth (Chough et al., 2000). The E/JS is considered as a miniature ocean, since it has typical characteristics of open oceans, such as a deep ventilation system, subpolar and subtropical gyres, and a western boundary current (Masuda, 2000). The E/JS has three deep basins (Ulleung Basin, Yamato Basin, and Japan Basin). The UB, located in the southwestern part of the E/JS, is surrounded by continental slopes of the Korean Peninsula, the southwestern part of Japan's main island of Honshu, and Ulleung and Dok island (Fig. 1). The northern and western margins of the basin are steep $\left(>10^{\circ}\right)$, whereas the southern and eastern margins have smooth slopes $\left(1 \sim 2^{\circ}\right)$ and a broad continental shelf (Park et al., 2005). The basin floor lies at depths of $2000 \sim 2300 \mathrm{~m}$, with the boundary between the continental slope and the UB approximately $2000 \mathrm{~m}$ in depth. Recent sediments appear to be primarily hemipelagic (Chough and Brag, 1987), no major rivers drain into the basin along the coast of the Korean Peninsula (Ikehara et al., 1994; Hong et al., 2008).

This study focused on OC cycle at the sediment-water interface and ultimately removal of OC in the UB sediments. The E/JS is a small local sea, but it is similar to the characteristics of the ocean. It is therefore the most suitable model for studying the carbon sinking to the deep ocean floor. The main purpose of this paper is to present a carbon storage and removal mechanisms of deep UB sediments, and to understand role of deep basin sediment for the removal of $\mathrm{CO}_{2}$ from the E/JS surface water. This result is crucial for future carbon cycle and deep ocean ecosystem modelling.

\section{Materials and methods}

\section{Sediment sampling and analyses}

Sediment samples were collected using a box corer at sites on the deep basin (D2, D3, and D4) in April 2006 and August 2007. Sediment samples for geochemical analysis were collected from the box core using acrylic core samplers $(8 \mathrm{~cm}$ i.d.) that were then immediately sealed with polyethylene stoppers (Fig. 2). The core samples 
were transferred to the laboratory onboard the research vessel, where the sediment was sectioned at intervals of 1 or $2 \mathrm{~cm}$ and transferred to acid-cleaned polyethylene bottles that were sealed with caps. The sediment samples for measuring organic carbon content, total nitrogen content, $\mathrm{CaCO}_{3}$ content, opal content, sediment density, water content, and ${ }^{210} \mathrm{~Pb}$ activity were stored at $4{ }^{\circ} \mathrm{C}$.

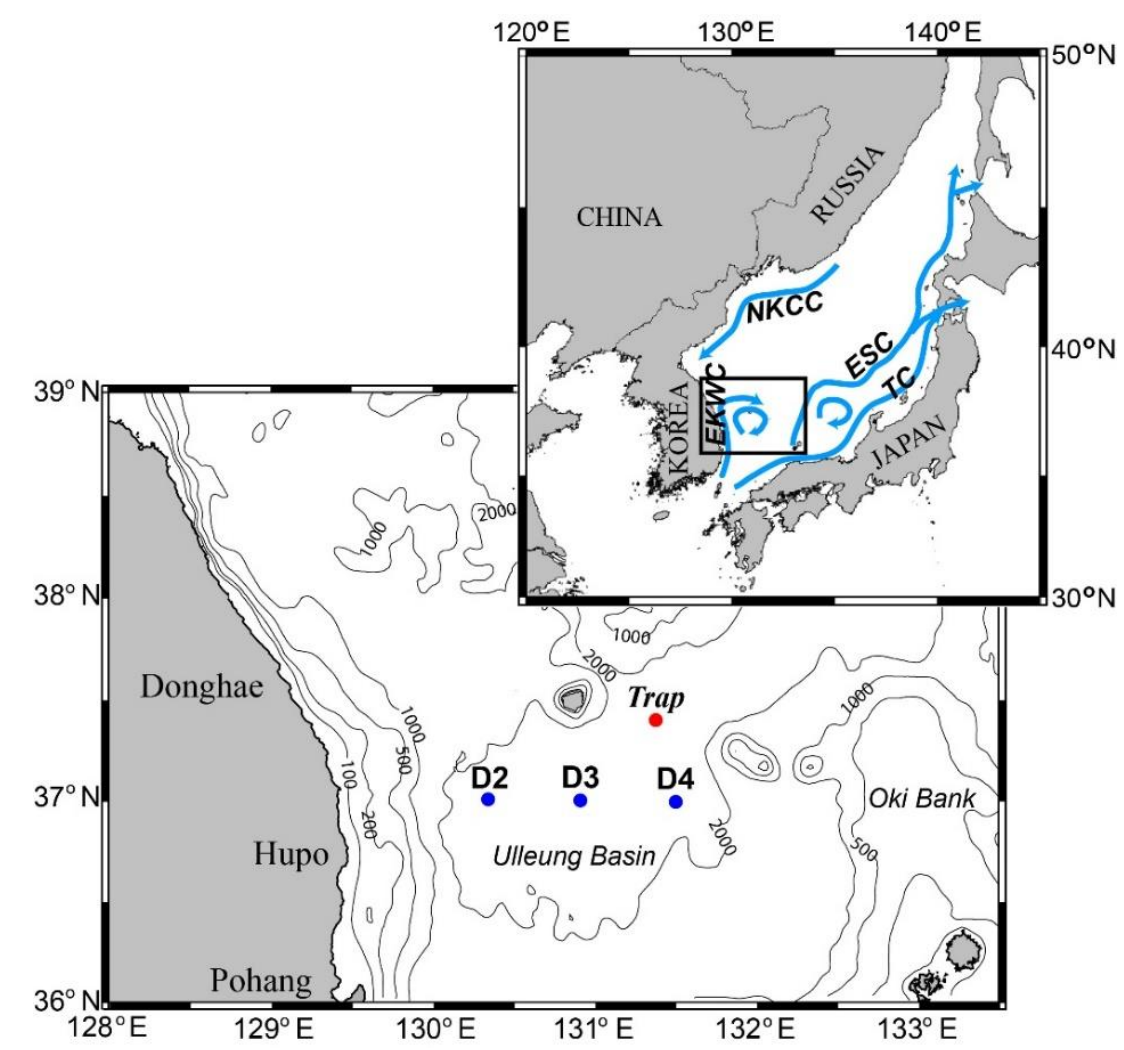

Figure 1. Study area and sampling sites in the Ulleung Basin, East/Japan Sea. Trap is sediment trap mooring site (KORDI, 2003)

The organic carbon content was determined by comparing the total carbon measured by a Carlo Erba NA 1500 nitrogen-carbon-sulfur (NCS) analyzer to the inorganic carbon content measured by a Coulometrics inorganic carbon analyzer. Dried samples were combusted at $900^{\circ} \mathrm{C}$ in an oxygen atmosphere in the NCS analyzer. The resulting products were chromatographically separated and quantified to obtain the total carbon and total nitrogen contents.

\section{Calculation of the sedimentation rate and sediment mass accumulation rate (MAR)}

Dried sediment samples taken from various depths were used to determine the sediment density and porosity. Density was measured by a Micromeritics AccuPyc 1330 density analyzer, and porosity was calculated from water content. A portion of the dried samples were ground and spiked with a known quantity of ${ }^{208}$ Po to determine the accuracy of the analyses. These samples were leached and brought to dryness three times in the presence of concentrated $\mathrm{HNO}_{3}$ and $6 \mathrm{~N} \mathrm{HCl}$. Dilute $\mathrm{HCl}$ was then added to the sample, and the solution was separated from the residual solids by centrifugation. For each sample, the dissolved polonium isotopes were plated onto a silver planchet. 
The ${ }^{210} \mathrm{~Pb}$ activity was determined by measuring the alpha activity of its granddaughter, ${ }^{210} \mathrm{Po}$, using a silicon-surface-barrier detector coupled to a multi-channel analyzer. All measurements were conducted at the Korea Basic Science Institute.

Aparent sedimentation rates (ASR) were estimated based on the ${ }^{210} \mathrm{~Pb}$ profiles. The exact relation is Equation 1.

$$
S=-\lambda / b
$$

where $S$ is the sedimentation rate $\left(\mathrm{cm} \mathrm{year}{ }^{-1}\right), \lambda$ is the decay constant of ${ }^{210} \mathrm{~Pb}$ $\left(0.0311\right.$ year $\left.^{-1}\right)$, and $b$ is the slope of the curve. The calculation of sedimentation rates assumes that the excess ${ }^{210} \mathrm{~Pb}$ flux and sedimentation are constant over time. Sedimentation rates calculated from profiles of excess ${ }^{210} \mathrm{~Pb}$ activity often overestimate actual accumulation rates because the gradual decrease in mixing efficiency with increasing depth results in a depth profile indicating exponential decay (Niggemann et al., 2007), which can be falsely interpreted as undisturbed sediment accumulation.

The sediment mass accumulation rate (MAR) was calculated by following Equation 2.

$$
\operatorname{MAR}\left(\mathrm{g} \mathrm{m}^{-2} \text { year }^{-1}\right)=(1-\varphi) \times \operatorname{GD}\left(\mathrm{g} \mathrm{cm}^{-3}\right) \times \operatorname{ASR}\left(\mathrm{cm} \text { year }{ }^{-1}\right) \times 10^{4}
$$

where $\varphi$ is porosity, and GD is sediment grain density. The porosity was calculated from the water content. At all stations, water contents decreased rapidly within the top $10-15 \mathrm{~cm}$ and were relatively constant below it. We used an average of porosities below $15 \mathrm{~cm}$ at each station for the MAR calculation. An average of GD below $15 \mathrm{~cm}$ was also used for the MAR calculation.
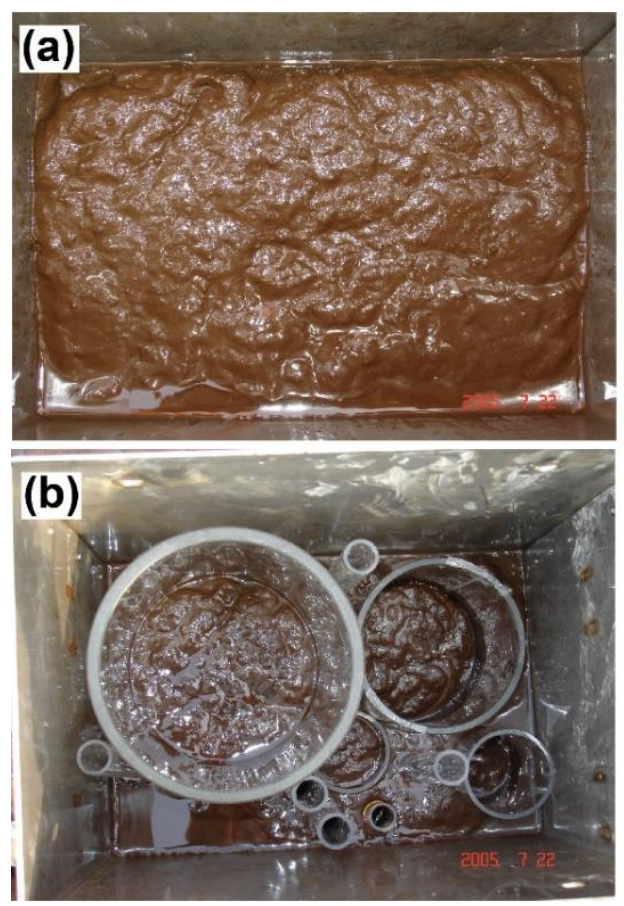

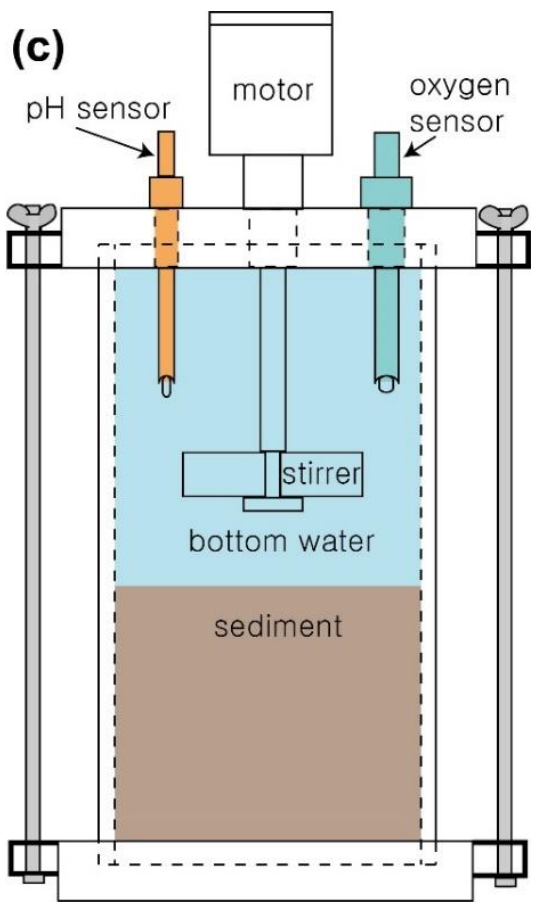

Figure 2. Photographs of (a) sediment sampling using a box corer and (b) subsampling for geochemical analyses and sediment incubation chamber experiment. A schematic diagram of (c) sediment incubation chamber (Lee et al., 2019) 


\section{Sediment incubation for calculation of oxygen consumption rate (OCR)}

Bottom water taken from the Rosette-sampler was carefully added on top of the sediment at each stations where sediment sampling was performed using the box corer (Fig. 2). The water column height overlying the $30 \mathrm{~cm}$ sediment core was $18 \mathrm{~cm}$, corresponding to a water volume of approximately $2 \mathrm{~L}$. Immediately after adding bottom water, acryl cover was put on acryl core liner without trapping any air. The core was incubated together with the overlying water at approximately in-situ temperature $\left(0.4^{\circ} \mathrm{C}\right)$ in a darkened, refrigerator for benthic exchange measurement of oxygen. A stirring speed in the overlying water of approximately $9 \mathrm{rpm}$ was obtained by using a Poly Ethylene stirring bar attached to a Poly Ethylene rod $10 \mathrm{~cm}$ above the sediment surface during incubation time of 1-2 days (Fig. 2). The sediment incubation was performed until the oxygen was completely depleted or the reduction in oxygen became steady. At the beginning and end of the incubation, overlying water was collected, and the DO concentration was adjusted via Winkler titration. The oxygen consumption rate (OCR) was estimated by reference to the changes in the concentrations measured by the respective sensors in the chamber (Lee et al., 2019), and calculated using the Equation 3.

$$
F=d C / d t \times V / A
$$

where $F$ is the net flux of substance via the water-sediment boundary layer $\left(\mathrm{mmol} \mathrm{m} \mathrm{m}^{-2} \mathrm{day}^{-1}\right), d C / d t$ is the slope of the changes in the concentration of oxygen over time $\left(\mathrm{mmol} \mathrm{L}^{-1} \mathrm{~d}^{-1}\right), V$ is the chamber volume $(\mathrm{L})$, and $A$ is the area of the chamber's horizontal plane $\left(\mathrm{m}^{2}\right)$.

\section{Surface chlorophyll-a concentration}

The monthly surface chlorophyll-a concentration $\left(\mathrm{mg} / \mathrm{m}^{3}\right)$ were used MODerate resolution Imaging Spectroradiometer (MODIS)-aqua level 3 data $(4 \times 4 \mathrm{~km}$ spatial resolution and Standard Mapped Image (SMI) projection) and obtained from NASA Ocean Biologoy Processing Group (http://oceancolor.gsfc.nasa.gov/). The chlorophyll-a concentration data on August, 2007 covered the study area was resampled from the level 3 data.

\section{Results}

\section{Surface sediment characteristics}

Figure 3 shows contents of the total organic carbon (TOC), total nitrogen (TN), calcium carbonate $\left(\mathrm{CaCO}_{3}\right)$ and biogenic opal $(\mathrm{Si})$ in the UB sediment. TOC contents in the surface sediments were over $2.6 \%$ except station D3. TOC contents profiles showed dramatically decreasing from 2.6 to $1.7 \%$ in the uppermost $5 \mathrm{~cm}$, and slightly decline below it. TN content profiles displayed same profiles of organic carbon contents at all stations. At surface sediments, TN contents varied from $0.25 \%$ to $0.4 \%$. At all stations, calcium carbonate contents were under $1 \%$ at whole depth. The Si contents ranged from $10 \%$ to $16 \%$ at stations D2 and D4 (Fig. 3).

TOC contents are positively correlated with TN values at the UB sediments, with mean TOC/TN $(\mathrm{C} / \mathrm{N})$ molar ratio of 7.09 , which is almost same as the Redfield ratio (6.63), indicating that the organic matter deposited in the UB is predominantly of 
marine origin. Biogenic opal/TOC (Si/C) ratio ranged from 4.8 to 9.9 , with a mean $\mathrm{Si} / \mathrm{C}$ ratio is 7.2 (Fig. 4). The mean $\mathrm{Si} / \mathrm{C}$ ratio of station $\mathrm{D} 2$ is 7.6, and station D4 is 6.7.

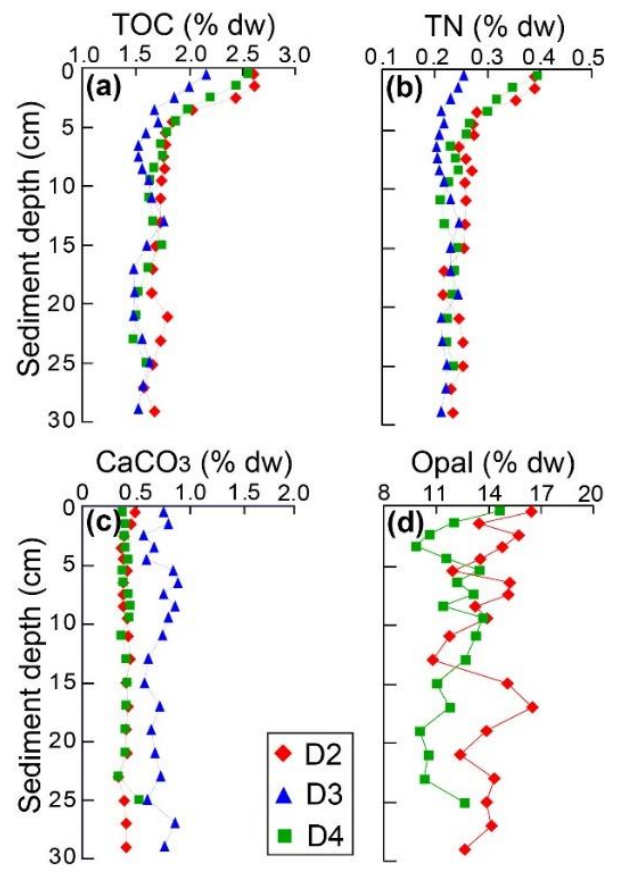

Figure 3. Depth profiles of (a) total organic carbon (TOC), (b) total nitrogen (TN), (c) calcium carbonate $\left(\mathrm{CaCO}_{3}\right)$ and $(\mathrm{d})$ biogenic opal in the Ulleung Basin sediment. In site D3, the biogenic opal content could not be analyzed
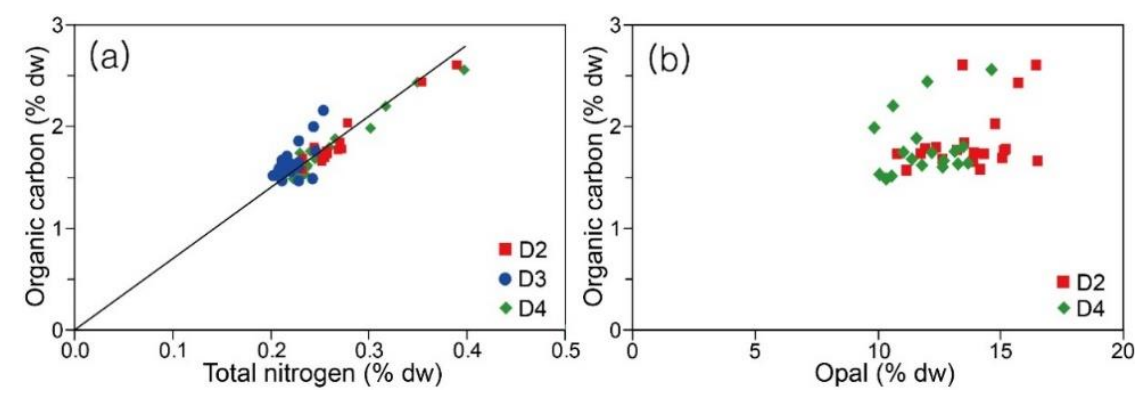

Figure 4. Organic carbon versus (a) total nitrogen contents and (b) biogenic opal contents at the Ulleung Basin sediment. The C/N ratio was calculated from the slope of the best-fit regression line

\section{Sedimentation rate}

Sedimentation rates were calculated primarily from excess ${ }^{210} \mathrm{~Pb}$ distribution, with the common assumption that fluxes of sediment and the associated excess ${ }^{210} \mathrm{~Pb}$ activity are reasonably constant on decadal to centennial timescales in the UB. The apparent sedimentation rates (ASR) varied between $0.036-0.047 \mathrm{~cm} \mathrm{year}^{-1}$ (Fig. 5). The sediment mass accumulation rate (MAR) was calculated by porosity, sediment grain density (GD), and ASR in UB sediments. The porosity varied from 0.85 to 0.86 , and the GD varied from 2.61 to $2.63 \mathrm{~g} \mathrm{~cm}^{-3}$ (Table 1). The calculated MARs ranging from 131 to $184 \mathrm{~g} \mathrm{~m}^{-2}$ year $^{-1}$, was relatively higher at the station D3 than at the station D4. 


\section{Organic carbon fluxes in the sediment}

Time-series sediment trap was deployed at 2,100 $\mathrm{m}$ water depth in the UB from December 1998 to January 2000 (KORDI, 2003), which reported that OC content was approximately 6\%. Input flux of organic carbon (IF) was calculated from the MAR and OC content at $2,100 \mathrm{~m}$ water depth. The calculated IFs varied from 7.89 to $11.08 \mathrm{gC} \mathrm{m}^{-2}$ year ${ }^{-1}$. Burial flux of organic carbon (BF) was calculated from the MAR and the averaged $\mathrm{OC}$ content below the sediment depth $15 \mathrm{~cm}$ where it was not changed considerably (Fig. 3). The calculated BFs varied between 2.02-3.10 $\mathrm{gC} \mathrm{m}^{-2}$ year $^{-1}$ (Table 1).

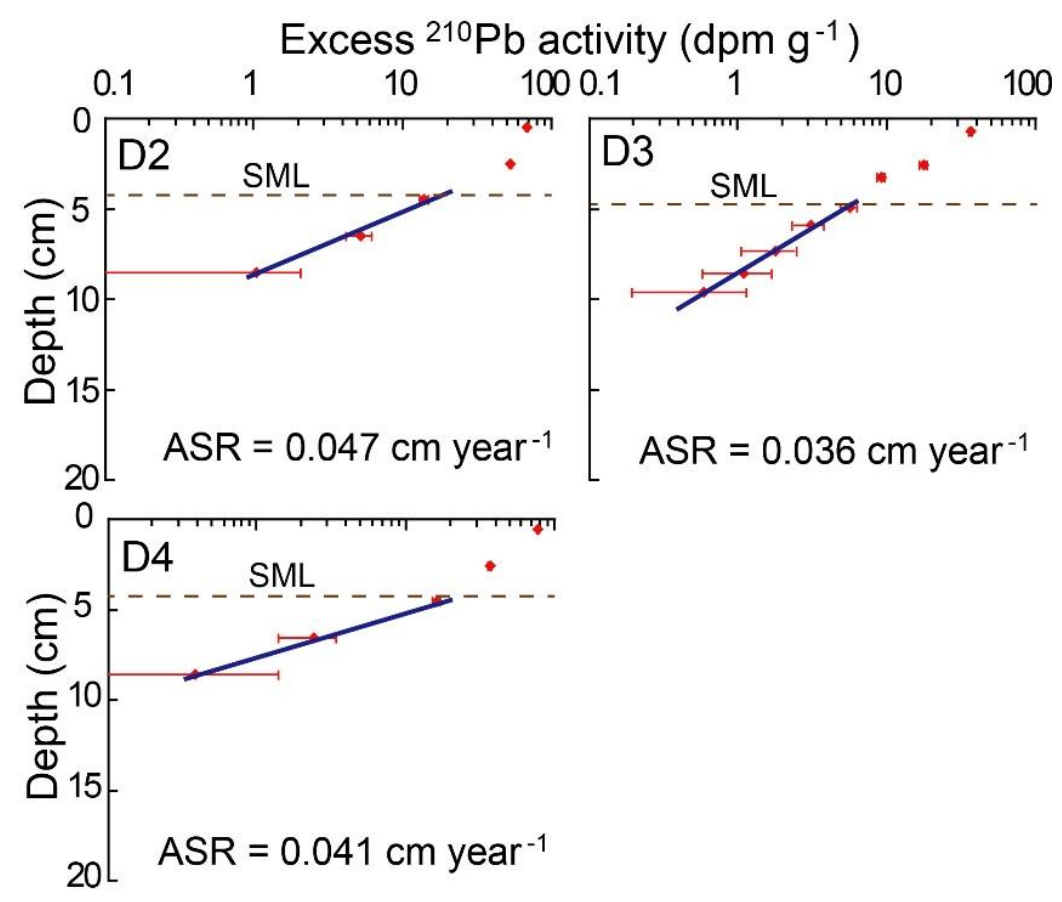

Figure 5. Depth profiles of excess ${ }^{210} \mathrm{~Pb}$ activities (error bars denote standard deviations) at site D2, D3 and D4 in Ulleung Basin sediment. The dotted lines indicate the surface mixed layer

$(S M L)$

Table 1. Water depth $(m)$, Porosity $(\varphi)$, grain density $(G D)$, apparent sedimentation rate $(A S R)$, mass accumulation rate (MAR), Input flux of organic carbon (IF), regenerated flux of organic carbon $(R F)$, and burial flux of organic carbon $(B F)$ in the Ulleung Basin sediment

\begin{tabular}{|c|c|c|c|c|c|c|c|c|}
\hline \multirow{2}{*}{ Site } & \multirow{2}{*}{\begin{tabular}{|c|} 
Water \\
Depth $(\mathrm{m})$
\end{tabular}} & \multirow[b]{2}{*}{$\varphi$} & \multirow{2}{*}{$\begin{array}{c}\text { GD } \\
\left(\mathrm{g} \mathrm{cm}^{-3}\right)\end{array}$} & \multirow{2}{*}{$\begin{array}{c}\text { ASR } \\
\left(\mathrm{cm} \mathrm{year-1)}^{-1}\right)\end{array}$} & \multirow{2}{*}{$\begin{array}{c}\text { MAR } \\
\left(\mathrm{g} \mathrm{m}^{-2} \text { year }^{-1}\right)\end{array}$} & IF & RF & BF \\
\hline & & & & & & \multicolumn{3}{|c|}{$\left(\mathrm{gC} \mathrm{m}^{-2}\right.$ year $\left.^{-1}\right)$} \\
\hline D2 & 2,208 & 0.85 & 2.62 & 0.047 & 184 & 11.08 & $6.59(7.98)^{\mathrm{a}}$ & 3.10 \\
\hline D3 & 2,190 & 0.86 & 2.61 & 0.036 & 131 & 7.89 & $6.22(5.87)^{\mathrm{a}}$ & 2.02 \\
\hline D4 & 2,143 & 0.85 & 2.63 & 0.041 & 161 & 9.70 & $6.22(7.15)^{\mathrm{a}}$ & 2.55 \\
\hline
\end{tabular}

${ }^{\text {a }}$ Regenerated flux of organic carbon calculated by subtracting burial flux from input flux

In sediments underlying well-oxygenated bottom waters, oxygen is the most important electron accepter for organic matter decomposition. The sedimentary oxygen consumption rate (OCR) is a good first-order indicator of organic matter oxidation rates in many locations. Concentrations of oxygen in the overlying water decreased linearly 
with time over the entire period of the sediment incubations in this study (Fig. 6). A linear decrease was to be expected since oxygen concentration did not decrease by more than $5-10 \%$ of the almost initial bottom water values. At the stations D2 and D3 in April 2006, sedimentary OCRs were 1.85 and $2.05 \mathrm{mmol} \mathrm{m}^{-2}$ day $^{-1}$, respectively. At the stations D2 and D4 in August 2007, the measured sediment OCRs were 1.87 and $1.85 \mathrm{mmol} \mathrm{m}^{-2}$ day $^{-1}$, respectively (Fig. 6).

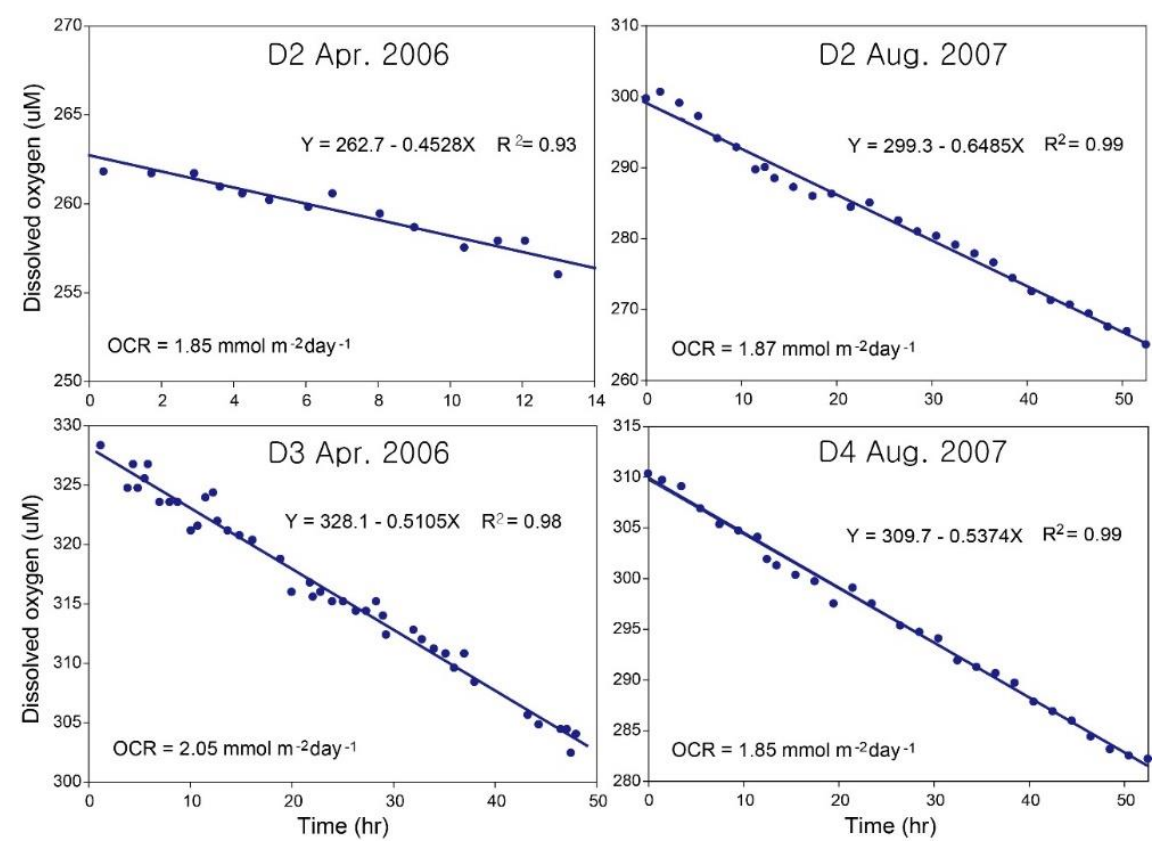

Figure 6. Time-series of dissolved oxygen concentration in overlying water of chamber experiment at sites D2 and D3 in basin sediment in April 2006, at sites D2 and D4 in August 2007. The solid lines indicate the result of linear regression at considerable oxygen reduced section

Regenerated flux of organic carbon (RF) was calculated from the sedimentary OCR, since oxygen most likely is the predominant electron acceptors in the mineralization process of sediment, and the oxygen is used in the reduction of the reduced species. In deep sediment, $90 \%$ of oxygen is consumed in the mineralization of organic matter and the rest is consumed in the reduction of the reduced species. So, the oxygen consumption and mineralization of organic matter coincides with nearly. In general, 138 moles of oxygen needed to oxidize 106 moles of organic carbon undergoing mineralization. At the stations D2 and D3 in April 2006, the RFs calculated with the OCR were 6.22-6.90 $\mathrm{gC} \mathrm{m}^{-2}$ year $^{-1}$, respectively. At the stations D2 and D4, the RFs were 6.29-6.22 $\mathrm{gC} \mathrm{m}^{-2}$ year $^{-1}$ in August 2007, respectively (Table 1).

\section{Discussion}

\section{Sedimentary organic carbon}

At the UB, the high organic contents $(>2.5 \%)$ are rarely found in the deep sea sediments, except for the Black Sea with a large river discharge (Cociasu et al., 1996; Reschke et al., 2002) and the Chilean upwelling areas with high primary productivity 
(Schubert et al., 2000; Böning et al., 2005). The UB sediments are less influenced by river discharge since no major rivers drain into the sea along the east coast of Korea (Ikehara et al., 1994).

In the UB, OC flux estimated by the Honjo-type time-series sediment trap was $8.8 \mathrm{gC} \mathrm{m}^{-2}$ year $^{-1}$ at the $1020 \mathrm{~m}$ water depth from December 1998 to January 2001 (KORDI, 2003), which is about 3 times higher than that in the Bering Sea (Takahashi et al., 2000) and comparable with that in the Chilean upwelling area (Hebbeln et al., 2000). Therefore, the high OC contents in the UB appear to be resulted from the high export production in this area. Besides the high export production, the high OC contents in the UB may be due to the less dilution effect by calcium carbonate (Lee et al., 2008). Chen et al. (1995) suggested that carbonate saturation depths for aragonite and calcite in the E/JS were 300 and $1300 \mathrm{~m}$, respectively. Thus, calcium carbonate contents in the UB sediments were less than $1 \%$ (Fig. 3), which caused the high OC contents in the UB.

The OC and TN values were used to calculate the $\mathrm{C} / \mathrm{N}$ molar ratios, which were used to identify whether sedimentary organic matter had originated from algal or land-plant sources. The average $\mathrm{C} / \mathrm{N}$ molar ratio is 7.09 (Fig. 4). Algae have $\mathrm{C} / \mathrm{N}$ molar ratios between 4 and 10, whereas vascular land plants have ratios of 20 or greater (Jasper and Gagosian, 1990; Meyers, 1994; Prahl et al., 1994). The average Si/C ratios are 7.6 and 6.7 in sites D2 and D4, respectively (Fig. 4). The typical stoichiometric proportion of OC to biogenic opal in diatoms with adequate light and nutrients is approximate 7 (Haskell et al., 2013), this suggests that the deposited organic matter in the UB sediment was predominantly of diatoms.

In the UB sediment, more than $80 \%$ of deposited organic matter is composed of marine origin biogenic matter, which are dominated by silicate diatoms (Niggemann et al., 2007). In the surface ocean, they sink with POC and ballast minerals, such as siliceous opal and $\mathrm{CaCO}_{3}$ at the same time (Amstrong et al., 2001; Honda and Watanabe, 2010). $\mathrm{A} \mathrm{CaCO}_{3}$ is mostly dissolved at a $1,300 \mathrm{~m}$ or shallower water depth, but POC and opal settle down on the deeper sea bed. Therefore, at over 2,100 m water depth, the $\mathrm{CaCO}_{3}$ was slightly dissolved and did not significantly affect POC flux. However, the POC sink with high content of biogenic opal, leading to higher POC flux, which may have increased the OC content in the UB sediment.

\section{Fluxes of organic carbon in the sediment}

The ASR tends to decrease with increasing water depth, which is consistent with the previous result found by Hong et al. (1997) in the UB. In addition, the sedimentation rates of this study are very similar to those measured by Hong et al. (1997), 0.04-0.17 $\mathrm{cm}_{\text {year }}{ }^{-1}$, in the same study area. Miralles et al. (2005) proposed an inverse linear relationship between the ASR and water depth in the northwestern Mediterranean margin sediments; ASR $\left(\mathrm{cm}^{\text {year }}{ }^{-1}\right)=0.155-4.978 \times 10^{-5} \times$ water depth $(\mathrm{m})$. This relation holds strongly in this study area, with only $10 \%$ deviation between the measured values and the expected values from the above relationship.

The high $\mathrm{BF}$ values (over $2 \mathrm{gC} \mathrm{m}^{-2}$ year $^{-1}$ ) have rarely been found in the deep sea sediments (deeper than $2000 \mathrm{~m}$ ), except for the Black Sea deep basin and intense upwelling areas. The BFs obtained from the deep basin of the Black Sea are similar to, or 2-3 times higher than those in the UB (Hay, 1998). In the Peruvian and Namibian upwelling areas, the IF is about an order of magnitude higher than in the UB (Calvert and Price, 1983; Böning et al., 2004). Although MAR estimated in the northern Gulf of 
Mexico is similar to that in the UB, the IF is much lower due to low organic carbon contents (Yeager et al., 2004).

Since oxygen respiration is the principal mineralization process in the sediment of the UB (Lee et al., 2008), a respiratory quotient of 0.77 , which is consistent with the Redfiled stoichiometry for the oxidation of organic matter. But Accornero et al. (2003) presented that a respiratory quotient of 0.85 was assumed to convert sediment oxygen consumption into organic carbon remineralization in the sediment of the Gulf of Lions. In the conversion of oxygen consumption into mineralization rates, we assumed that oxygen was consumed by re-oxidation of reduced components within the sediment chamber. This process was found to significantly affect OC oxidation in other continental margin sediments (Canfiel et al., 1993). Previous studies have demonstrated that in sediments of the UB, oxygen and other processes such as Mn-oxide and Fe-oxide reduction, sulfate reduction does play a considerable role in the OC oxidation (Lee et al., 2008; Choi et al., 2009). In the UB, near the sediment-water interface is anoxic condition due to oxygen penetration depth is a few millimeters, and stimulate the heterotrophic activity. Consequently, converted RF by OCR is lower than calculated RF by subtracting BF from IF (Table 1).

\section{Organic carbon cycle in the Ulleung Basin}

In the UB, Hahm and Kim (2001) estimated the export flux of OC (EF, $64 \mathrm{gC} \mathrm{m}^{-2}$ year $^{-1}$ ) using tritium and helium isotopes and Kim et al. (2011) determined an annual average $\mathrm{EF}\left(59 \pm 3 \mathrm{gC} \mathrm{m}^{-2}\right.$ year $\left.{ }^{-1}\right)$ using ${ }^{238} \mathrm{U} /{ }^{234} \mathrm{Th}$ disequilibrium. Based on Kim et al. (2011) seasonal average EFs were 216.0, 102.2, 55.2 and $84.2 \mathrm{mgC} \mathrm{m}^{-2}$ day $^{-1}$ in spring, summer, autumn and winter, respectively. In spring, the EF was higher than other seasons. This value was attributed to the highest value of the phytoplankton biomass, and the primary production was higher than in summer and autumn. In summer, the EF was moderate value. In autumn, the value was about four times lower than spring. This lower EF value was attributed to the lower primary production in autumn. In winter, however, despite of high primary production, the EF was relatively very low.

Berger et al. (1989) suggested the proportions of OC export flux to primary production in the world open ocean and coastal ocean. The world open ocean and coastal ocean EF/PP ratios are 0.10 and 0.25 , respectively. The annual average primary production in the UB was about $177.1 \mathrm{gC} \mathrm{m}^{-2}$ year $^{-1}$ (Kim et al., 2011), the EF/PP ratios are 0.36, 0.07 and 0.29 at station D2, D3 and D4, respectively (Table 2), average EF/PP ratio is 0.299 (Kim et al., 2011). Satellite-derived primary production ranged between 161-222 $\mathrm{gC} \mathrm{m}^{-2}$ year $^{-1}$ in the E/JS and the UB is much higher than the Japan basin (Yamada et al., 2005). The EF in the UB was 2 times higher than the world open oceans.

The exported POC from the UB surface ocean is one of the largest sinks of atmospheric carbon dioxide. For example, Figure 7 showed the satellite-derived chlorophyll-a concentration image in August, 2007. Increasing chlorophyll-a concentration was covered in the study area compared to around area. Hyun et al. (2009) proposed that phytoplankton and bacterioplankton production is enhanced by coastal upwelling and anticyclonic eddy (i.e. Ulleung warm eddy) in the UB. Omand et al. (2015) proposed that a submesoscale eddy-driven flux of POC is unresolved in global carbon cycle models but can contribute as much as half of the total springtime export of POC from the highly productive oceans. Yoo and Park (2009) suggested that the southwest region in the E/JS is highly productive due to southerly wind-driven 
coastal upwelling from spring to fall. Various studies noted that East Korea Warm Current (EKWC) is important factor, which the production in the coastal region transported into the UB by anticyclonic Ulleung Warm Eddy (Isoda and Saitoh, 1993; Michell et al., 2005; Hyun et al., 2009). Time-series sediment trap was deployed at 2100 $\mathrm{m}$ water depth in the UB from December 1998 to January 2000 in order to estimate an annual flux of particulate matter (KORDI, 2003), which was $122 \mathrm{~g} \mathrm{~m}^{-2}$ year ${ }^{-1}$, less than the MAR (161 $\mathrm{g} \mathrm{m}^{-2}$ year $\left.^{-1}\right)$ estimated at site D4. The location of sediment trap deployment was apart about $50 \mathrm{~km}$ from site D4 (Fig. 1). The site D4 located in eddy region, so export production at $\mathrm{D} 4$ is higher than that of sediment trap mooring site.

Table 2. POC Export flux (EF), Input flux $(I F)$, regenerated flux $(R F)$, and burial flux $(B F)$ of organic carbon/primary production $(P P)$ ratios in the Ulleung Basin. The average primary production in the Ulleung Basin was about $177.1 \mathrm{gC} \mathrm{m}^{-2}$ year ${ }^{-1}$ (Kim et al., 2011). Open ocean and Coastal ocean are the average proportions of organic carbon flux to primary production in the world open ocean and coastal ocean (Berger et al., 1989)

\begin{tabular}{c|c|c|c|c}
\hline Site & $\begin{array}{c}\text { EF / PP } \\
\text { ratio }\end{array}$ & $\begin{array}{c}\text { IF / PP } \\
\text { ratio }\end{array}$ & $\begin{array}{c}\text { RF / PP } \\
\text { ratio }\end{array}$ & $\begin{array}{c}\text { BF / PP } \\
\text { ratio }\end{array}$ \\
\hline D2 & 0.328 & 0.062 & 0.045 & 0.017 \\
D3 & 0.062 & 0.044 & 0.033 & 0.012 \\
D4 & 0.254 & 0.055 & 0.040 & 0.015 \\
\hline Ave. $\boldsymbol{U B}$ & 0.211 & 0.054 & 0.039 & 0.015 \\
Coastal ocean & 0.100 & 0.010 & 0.009 & 0.001 \\
\hline
\end{tabular}

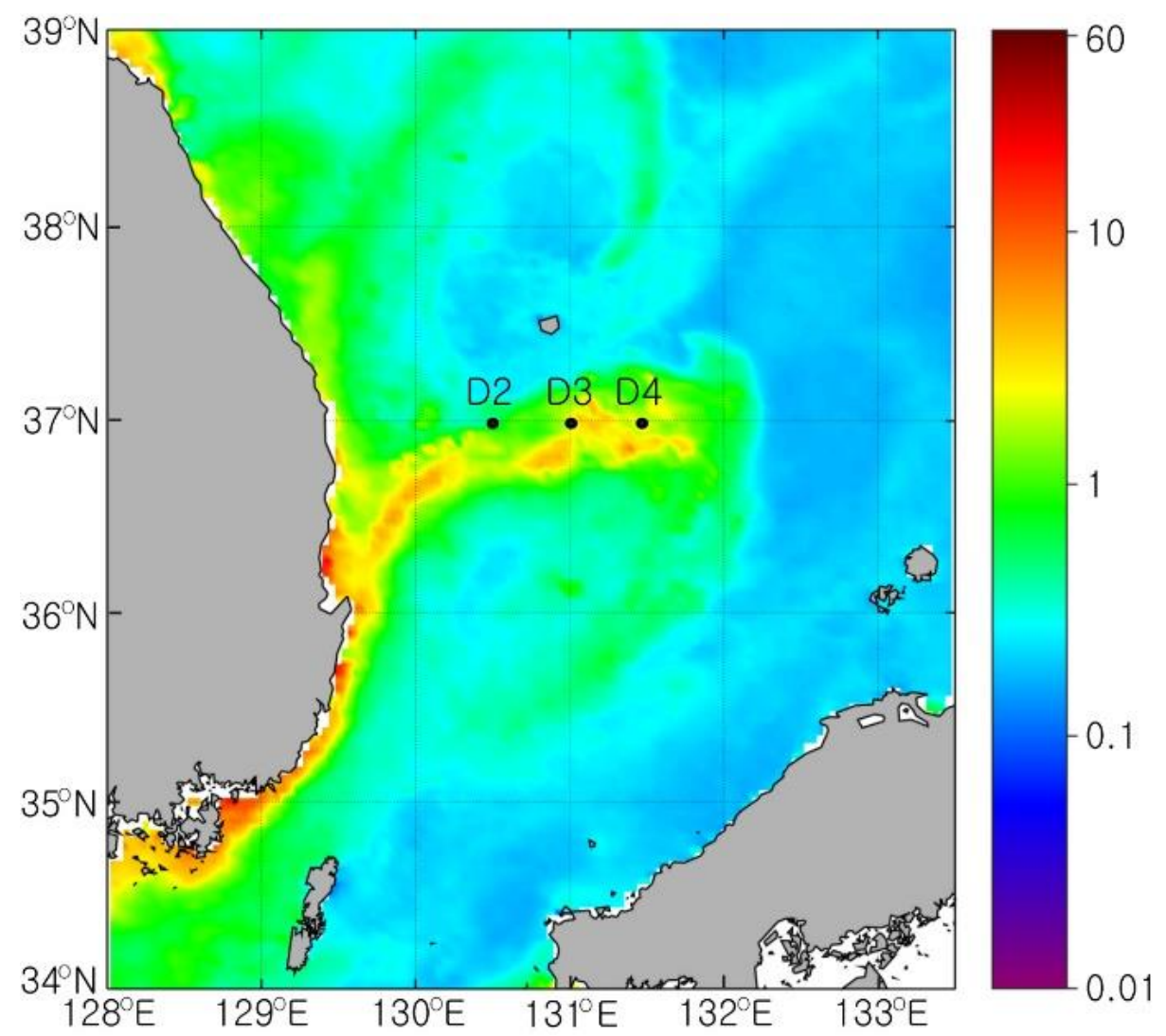

Figure 7. Monthly mean of surface chlorophyll-a concentration derived from MODIS-aqua in the Ulleung Basin in August, 2007 
Berger et al. (1989) suggested the proportions of IF, RF, and BF to primary production in the world open ocean and coastal ocean. In the world open ocean and coastal ocean benthic boundary layer, IF/PP ratios are about 0.010 and 0.066 , respectively. In the UB deep benthic boundary layer, IF/PP ratio is 0.054 (Table 2). In the UB, the POC input to the benthic boundary layer is 5 times higher than in the world open ocean. In the world open ocean, coastal ocean, and UB sediments, RF/PP ratios are about $0.009,0.058$, and 0.039 , respectively. The BF/PP ratios are $0.001,0.008$, and 0.015 in the open ocean, coastal ocean and UB, respectively (Table 2). Over $1 \%$ of primary production is buried on the UB sediment. It is a very rare case in the world coastal ocean and open ocean. Although a large value of IF in the coastal ocean sediment does not contribute significantly to carbon removal. In the coastal area, about $90 \%$ of OC deposited in sediments is remineralized, and returned to the water mass with $\mathrm{CO}_{2}$. In the UB sediment, however, only approximately $80 \%$ of the deposited OC is remineralized and approximately $20 \%$ is buried. It is important that the UB play a significant role in deep ocean carbon storage.

\section{Conclusion}

The UB sediment of E/JS are characterized by high OC contents and high IF of OC. High OC contents (over 2.5\%) and high IFs in the deep basin sediments have rarely been found, except for the Black Sea deep basin and intense upwelling areas. The high OC content appeared to result from high export production at surface water in UB. A mean organic matter $\mathrm{C} / \mathrm{N}$ molar ratio is 7.09 , indicating that the organic matter is predominantly of marine origin. The ASRs calculated by activities of excess ${ }^{210} \mathrm{~Pb}$ were ranged between 0.036-0.047 $\mathrm{cm}^{-1} \mathrm{yr}^{-1}$. The MARs calculated from the ASR and GD, ranged between 131-184 $\mathrm{g} \mathrm{m}^{-2}$ year $^{-1}$ and agree well with mass flux determined by the previous time-series sediment trap result $\left(122 \mathrm{~g} \mathrm{~m}^{-2}\right.$ year $\left.^{-1}\right)$. The IF and BF estimated by the MAR were ranged between 7.89-11.08 $\mathrm{gC} \mathrm{m}^{-2}$ year ${ }^{-1}, 2.02-3.10 \mathrm{gC} \mathrm{m}^{-2}$ year ${ }^{-1}$, respectively. The RF estimated by OCR were ranged $6.22-6.59 \mathrm{gC} \mathrm{m}^{-2}$ year $^{-1}$, but $\mathrm{RF}$ calculated by subtracting BF from IF were ranged between $5.87-7.98 \mathrm{gC} \mathrm{m}^{-2}$ year $^{-1}$. The average $\mathrm{IF} / \mathrm{PP}, \mathrm{RF} / \mathrm{PP}$ and $\mathrm{BF} / \mathrm{PP}$ ratios of $\mathrm{UB}$ sediments were $0.054,0.039$, and 0.015 , respectively.

In the UB, high proportion exported to the deep ocean with organic carbon produced by the primary production, high efficiency deposited to the deep boundary layer, high efficiency buried in the sediment. The UB might play an integral role in the deposition and removal of organic carbon. The area of E/JS is only $0.3 \%$ of the world ocean, however, may play a fundamental role in the global carbon cycle. These results show promise in terms of carbon cycle in the regions with high production input. The combined data on the in-situ and remote-sensing data clearly reproduce the understanding of the spatial and temporal pattern than is possible by using hydrographic cruise data. This approach is particularly important for interpreting deep waters in the regional and/or global scales.

Acknowledgements. The authors thank the captain, officers and crew of the $R / V$ Eardo who were most helpful in all our shipboard operations. We also thank to Dr. Jeong Hee Han of Korea Basic Science Institute, Republic of Korea for ${ }^{210} \mathrm{~Pb}$ measurements. This research was funded by KIOST, grant number PE99712 and titled "Biogeochemical cycling and marine environmental changes studies". 


\section{REFERENCES}

[1] Accornero, A., Picon, P., de Bovée, F., Charrière, B., Buscail, R. (2003): Organic carbon budget at the sediment-water interface on the Gulf of Lions continental margin. Continental Shelf Research 23: 79-92.

[2] Armstrong, R. A., Lee, C., Hedges, J. L., Honjo, S., Wakeham, S. G. (2001): A new, mechanistic model for organic carbon fluxes in the ocean based on the quantitative association of POC with ballast minerals. - Deep-Sea Research II 49: 219-236.

[3] Berger, W. H., Smetacek, V. S., Wefer, G. (1989): Ocean productivity and paleoproductivity - an overview, productivity of the oceans present and past. - In: Report of the Dahlem workshop on productivity of the ocean; Berlin, Life science research report 44, Wiley \& Sons, Chicherster, pp. 1-34.

[4] Böning, P., Brymsack, H. J., Böttcher, M. E., Schnetger, B., Kriete, C., Kallmeyer, J., Borchers, S. L. (2004): Geochemistry of Peruviam near-surface sediments. - Geochimica et Cosmochimica Acta 68: 4429-4451.

[5] Böning, P., Cuypers, S., Grunwald, M., Schnetger, B., Brumsack, H. J. (2005): Geochemical characteristics of Chilean upwelling sediments at $\sim 36^{\circ} \mathrm{S}$. - Marine Geology 220: 1-21.

[6] Calvert, S. E., Price, N. B. (1983): Geochemistry of Namibian sediments: Coastal upwelling, part A. - Response of the sedimentary regime to present coastal upwelling. Plenum, New York, USA, pp. 333-375.

[7] Canfiel, D. E., Jorgensen, B. B., Fossing, H., Glud, R., Gundersen, J., Ramsing, N. B., Thamdrup, B., Hansen, J. W., Nielsen, L. P., Hall, P. O. J. (1993): Pathways of organic carbon oxidation in the continental margin sediments. - Marine Geology 113: 27-40.

[8] Chen, C. T. A., Wang, S. L., Bychkov, A. S. (1995): Carbonate chemistry of the Sea of Japan. - Journal of Geophysical Research 100: 13737-13745.

[9] Choi, Y. J., Kim, D., Lee, T., Lee, C. B. (2009): Estimate of manganese and iron oxide reduction rates in slope and basin sediments of Ulleung Basin, East Sea. - Journal of Korean Society Oceanography 14: 127-133. (in Korean).

[10] Chough, S. K., Brag, E. (1987): Tectonic history of Ulleung basin margin, East Sea (Sea of Japan). - Geology 15(1): 45-48.

[11] Chough, S. K., Lee, H. J., Yoon, S. H. (2000): Marine Geology of Korean Seas. $-2^{\text {nd }}$ Ed, Elsevier, Amsterdam, 313p.

[12] Cociasu, A., Dorogan, L., Humborg, C., Popa, L. (1996): Long-term ecological changes in the Romanian coastal waters of the Black Sea. - Marine Pollution Bulletin 32: 32-38.

[13] Emeis, K. C., Struck, U., Leipe, T., Pollehne, F., Kunzendorf, H., Christiansen, C. (2000): Changes in the C, N, P burial rates in some Baltic Sea sediments over the last 150 yearsrelevance to $\mathrm{P}$ regeneration rates and the phosphorus cycle. - Marine Geology 167: 43-59.

[14] Hahm, D., Kim, K. R. (2001): An estimation of the new production in the southern East Sea using helium isotopes. - Journal of Korean Society Oceanography 36: 19-26. (in Korean).

[15] Haskell, W. Z., Berelson, W. M., Hammond, D. E., Capone, D. G. (2013): Particle sinking dynamics and POC fluxes in the Eastern Tropical South Pacific based on $234^{\text {Th }}$ budgets and sediment trap deployments. - Deep-Sea Research I 81: 1-13.

[16] Hay, B. J. (1998): Sediment accumulation in the central western Black Sea over the past 5100 years. - Paleoceanography 3: 491-508.

[17] Hebbeln, D., Marchant, M., Wefer, G. (2000): Seasonal variations of the particle flux in the Peru-Chile current at $30^{\circ} \mathrm{S}$ under 'normal' and El Nino conditions. - Deep-Sea Research II 47: 2101-2128. 
[18] Honda, M. C., Watanabe, S. (2010): Importance of biogenic opal as ballast of particulate organic carbon (POC) transport and existence of mineral ballast-associated and residual POC in the Western Pacific Subarctic Gyre. - Geophysical Research Letters 37: L02605, doi:10.1029/2009GL041521.

[19] Hong, G. H., Kim, S. H., Chung, C. S., Kang, D. J., Shin, D. H., Lee, H. J., Han, S. J. (1997): ${ }^{210} \mathrm{~Pb}$-drived sediment accumulation rates in the southwestern East Sea (Sea of Japan). - Geo-Marine Letters 17: 126-132.

[20] Hong, G. H., Kim, Y. I., Baskaran, M., Kim, S. K., Chung, C. S. (2008): Distribution of ${ }^{210} \mathrm{Po}$ and export of organic carbon from euphotic zone in the Southwestern East Sea (Sea of Japan). - Journal of Oceanography 64: 277-292.

[21] Hyun, J. H., Kim, D., Shin, C. W., Noh, J. H., Yang, E. J., Mok, J. S., Kim, S. H., Kim, H. C., Yoo, S. (2009): Enhanced phytoplankton and bacterioplankton production coupled to coastal upwelling and an anticyclonic eddy in the Ulleung basin, East Sea. - Aquatic Microbial Ecology 54: 45-54.

[22] Ikehara, K., Kikkawa, K., Oshima, H. (1994): Late Quaternary paleoenvironments of the Japan Sea as revealed by tephrochronology, AMS-14 dating and palynological data. - In: Proceedings of 1994 Sapporo Symposium global fluxes of carbon and its related substances in the coastal Sea-Ocean-Atmosphere system. pp. 505-510.

[23] Isoda, Y., Saitoh, S. (1993): The northward intruding eddy along the east coast of Korea. - Journal of Oceanography 49: 443-458.

[24] Jasper, J. P., Gagosian, R. B. (1990): The source and deposition of organic matter in the Late Quaternary Pygmy Basin, Gulf of Mexico. - Geochimica et Cosmochimica Acta 54: 117-132.

[25] Kim, D., Choi, M. S., Oh, H. Y., Song, Y. H., Noh, J. H., Kim, K. H. (2011): Seasonal export fluxes of particulate organic carbon from ${ }^{234} \mathrm{Th} /{ }^{238} \mathrm{U}$ disequilibrium measurements in the Ulleung Basin (Tsushima Basin) of the East Sea (Sea of Japan). - Journal of Oceanography 67: 577-588.

[26] KORDI. (2003): Marine ecosystem responses to climate variability in the East Sea. KORDI Tech. Rep. BSPE 825-00-1495-3 498p. (in Korean).

[27] Lee, T., Hyun, J. H., Mok, J. S., Kim, D. (2008): Organic carbon accumulation and sulfate reduction rates in slope and basin sediments of Ulleung Basin, East/Japan Sea. Geo-Marine Letters 28: 153-159.

[28] Lee, T., Kim, H. C., Son, Y. B. (2019): Sediment oxygen consumption and hydrogen sulfide release in hypoxic areas of Gamak Bay, Korea. - Applied Ecology and Environmental Research 17: 3199-3214.

[29] Leipe, T., Tauber, F., Vallius, H., Virtasalo, J., Uścinowicz, S., Kowalski, N., Hille, S., Lindgren, S., Myllyvirta, T. (2011): Particulate organic carbon (POC) in surface sediments of the Baltic Sea. - Geo-Marine Letters 31: 175-188.

[30] Masuda, A. (2000): Toward the clarification of variabilities in atmospheric and oceanic conditions in the Japan Sea. - In: Proceedings of $49^{\text {th }}$ conference of applied mechanics. pp. 285-288.

[31] Meyers, P. A. (1994): Preservation of elemental and isotopic source identification of sedimentary organic matter. - Chemical Geology 144: 289-302.

[32] Michell, D. A., Watts, D. R., Wimbush, M., Teague, W. J., Tracey, K. I., Book, J. W., Chang, K. I., Suk, M. S., Yoon, J. H. (2005): Upper circulation patterns in the Ulleung Basin. - Deep-Sea Research II 52: 1617-1638.

[33] Miralles, J., Radakovitch, O., Aloisi, J. C. (2005): ${ }^{210} \mathrm{~Pb}$ sedimentation rates from the Northwestern Mediterranean margin. - Marine Geology 216: 155-167.

[34] Niggemann, J., Ferdelman, T. G., Lomstein, B. A., Kallmeyer, J., Schubert, C. J. (2007): How depositional conditions control input, composition, and degradation of organic matter in sediments from the Chilean coastal upwelling region. - Geochimica et Cosmochimica Acta 71: 1513-1527. 
[35] Omand, M. M., D’Asaro, E. A., Lee, C. M., Perry, M. J., Briggs, N., Cetinic, I., Mahadevan, A. (2015): Eddy-driven subduction expores particulate organic carbon from the spring bloom. - Science 348: 222-225.

[36] Park, M. H., Kim, J. H., Kim, I. S., Ryu, B. J., Yu, K. M. (2005): Tehprostratigraphy and paleo-environmental implications of Late Quaternary sediments and interstitial water in the western Ulleung Basin, East/Japan Sea. - Geo-Marine Letters 25: 54-62.

[37] Prahl, F. G., Ertel, J. R., Goni, M. A., Sparrow, M. A., Eversmeyer, B. (1994): Terrestrial organic carbon contributions to sediments on the Washington margin. - Geochimica et Cosmochimica Acta 58: 3055-3048.

[38] Reschke, S., Ittekkot, V., Panin, N. (2002): The nature of organic matter in the Danube river particles and north-western Black Sea sediments. - Esturine, Coastal and Shelf Science 54: 563-574.

[39] Savoye, N., Benitez-Nelson, C., Burd, A. B., Cochran, J. K., Charette, M., Buesseler, K. O., Jackson, G. A., Roy-Barman, M., Schmidt, S., Elskens, M. (2006): ${ }^{234}$ Th sorption and export models in the water column: a review. - Marine Chemistry 100: 234-249.

[40] Schubert, C. J., Ferdelman, T. G., Strotmann, B. (2000): Organic matter composition and sulfate reduction rates in sediment of Chile. - Organic Geochemistry 31: 351-361.

[41] Seiter, K., Hensen, C., Schröter, J., Zabel, M. (2004): Organic carbon content in surface sediments-defining regional provinces. - Deep-Sea Research I 51: 2001-2026.

[42] Suess, E. (1980): Particulate organic carbon flux in the ocean-surface productivity and oxygen utilization. - Nature 288: 260-263.

[43] Summerhayes, C. P. (1981): Organic facies of middle Cretaceous black shales in deep north Atlantic. - AAPG Bulletin 65: 2364-2380.

[44] Takahashi, K., Fujitani, N., Yanada, M., Maita, Y. (2000): Long-term biogenic particle fluxes in the Bering Sea and central subarctic Pacific Ocean, 1990-1995. - Deep-Sea Research I 47: 1723-1759.

[45] Tissot, B. P., Demaison, G., Masson, P., Delteil, J. R., Combaz, A. (1980): Paleoenvironment and petroleum potential of middle Cretaceous black shales in Atlantic basins. - AAPG Bulletin 64: 2051-2063.

[46] Trull, T., Bray, S., Manganini, S., Honjo, S., Francois, R. (2011): Moored sediment trap measurement of carbon export in the Sub-antarctic and Polar Frontal Zones of the Southern Ocean, south of Australia. - Journal of Geophysical Research 106: 3148931509.

[47] Waples, J. T., Benitez-Nelson, C. R., Savoye, N., Rutgers van der Loeff, M., Baskaran, M., Gustafsson, O. (2006): An introduction to the application and future use of ${ }^{234} \mathrm{Th}$ in aquatic systems. - Marine Chemistry 100: 166-189.

[48] Yamda, K., Ishizaka, J., Nagata, H. (2005): Spatial and temporal variability of satellite estimated primary production in the Japan Sea from 1998 to 2002. - Journal of Oceanography 61: 857-869.

[49] Yeager, K. M., Santschi, P. H., Rowe, G. T. (2004): Sediment accumulation and radionuclide inventories $\left({ }^{239,240} \mathrm{Pu},{ }^{210} \mathrm{~Pb}\right.$ and $\left.{ }^{234} \mathrm{Th}\right)$ in the northern Gulf of Mexico, as influenced by organic matter and macrofaunal density. - Marine Chemistry 91: 1-14.

[50] Yoo, S., Park, J. (2009): Why is the southwest the most productive region of the East Sea/Sea of Japan? - Journal of Marine Systems 78: 301-315. 